\title{
Organic Manures: A Way to Improve Rhizospheral Microbial Population under Organic Cotton in Vertisols
}

\author{
Jayshree A. Khuspure ${ }^{1 *}$, S. M. Bhoyar ${ }^{1}$, P. W. Deshmukh ${ }^{1}$, \\ A. N. Paslawar ${ }^{2}$ and V. V. Gabhane ${ }^{1}$ \\ ${ }^{1}$ Department of Soil Science and Agriculture Chemistry, Dr. PDKV, Akola, India \\ ${ }^{2}$ Department of Agronomy, Dr. PDKV, Akola, India
}

*Corresponding author

Keywords

Bacterial, Fungal, Actimomycetes population

Article Info

Accepted: 04 September 2019 Available Online:

10 October 2019

\section{A B S T R A C T}

A field experiment was conducted during Kharif 2013-14 and 2014-15 at experimental fields of Cotton Research Unit CRU), Central Research Station (CRS), Dr. Panjabrao Deshmukh Krishi Vidyapeeth, Akola, to assess the effect of organic manures on rhizosphere fungal, bacterial and actinomycetes population in arboriu cotton (AKA-8) with eight sole organic treatments. The study revealed that significantly highest microbial population in the rhizosphere of cotton during 50\% flowering as well as $50 \%$ boll bursting stage was counted as $\left(100.33 \times 10^{6}\right.$ and $56.00 \times 10^{6}$ cfu $\mathrm{g}^{-1}$ ), fungi (52.67 $\times 10^{4}$ and $39.00 \times 10^{4} \mathrm{cfu} \mathrm{g}^{-1}$ ) and actinomycetes $\left(114.67 \times 10^{4}\right.$ and $\left.72.65 \times 10^{4} \mathrm{cfu} \mathrm{g}^{-1}\right)$ was recorded with treatment $\mathrm{T}_{3}$

\section{Introduction}

Rhizosphere microbial population plays a key role in soil nutrient recycling. However the residual toxic effect of inorganic fertilizers on rhizosphere microbial population is a matter of great concern. Extensive use of inorganics has often resulted in a marked decrease in rhizosphere microbial population (Azam and Banerjee, 1989 and Ganeshe et al., 1998) The application of organics favourably help in augmentation of beneficial microbial population and their activities such as organic matter decomposition, biological nitrogen fixation, phosphorus solublization and availability of plant nutrients through mineralization. The FYM serves as an excellent food for microorganisms.

The biological activity of a soil is the function of number of organisms present in soil and their physiological efficiency. The rate of respiration can be used as an index of the biological activity of soil as it reflects physiological efficiency of the organisms. All biological reactions in soils are catalyzed by 
enzymes. Soil enzyme activities are believed to indicate the extent of specific processes in soil and in some cases act as indicators of soil fertility. Increment in the bacterial population due to increments in doses of organic sources might be the fact that organic material acts as food for bacteria and as the quantity of food increased there was increased in their colonization for their energy requirement.

Sharma et al., (2000) found highest population of bacteria and fungi in FYM treated plots followed by incorporation of crop residues with lowest population of microorganism were recorded in only chemical fertilizer plots. Naidu et al., (1999) reported that application of manures and vermicompost with biofertilizer significantly harbored more microbes in soil over control. Similar result was also recorded by Maheswarappa et al., (1999). Halemani et al., (2004) reported significantly highest population of bacteria, fungi and actinomycetes with application of FYM alone @ 10 ton $\mathrm{ha}^{-1}$ followed by FYM @ 5 ton + cotton stalk residues 2.5 ton $\mathrm{ha}^{-1}$ and @ 5 ton + vermicompost.

Hence the present investigation was under taken to assess the influence of organic manures on rhizosphere microbial fungal, bacterial and actinomycetes population under semiarid conditions.

\section{Materials and Methods}

The present investigation was carried out at experimental fields of Cotton Research Unit CRU), Central Research Station (CRS), Dr. Panjabrao Deshmukh Krishi Vidyapeeth, Akola. The crop cotton was raised during Kharif 2013 and 2014. The experiment was laidout in simple randomized block design with three replications and comprised of 8 treatments viz., T1-Farm Yard Manure (FYM) $5 \mathrm{t} \mathrm{ha}^{-1}$, T2- vermicompost $2.5 \mathrm{t} \mathrm{ha}^{-1}$, T3-
FYM $10 \mathrm{t} \mathrm{ha}^{-1}$; T4- vermicompost $5 \mathrm{t} \mathrm{ha}^{-1}, \mathrm{~T}$ 5- in situ green manuring with Sunhemp, T6 Castor cake @ $500 \mathrm{~kg} \mathrm{ha}^{-1,}$ T7 - Sunhemp + FYM (source of $15 \mathrm{~kg} \mathrm{P}_{2} \mathrm{O}_{5}$ ) and $\mathrm{T} 8$ Control.

Organic manures were applied as basal dose. Biofertilizers were applied as seed treatment as well as soil treatment. Rhizospheral soil sample was taken at 50 per cent flowering and 50 per cent boll bursting stage of cotton to assess the status of soil bacterial, fungal and actinomycetes population. Fungal and bacterial populations were estimated by adopting serial dilution method (Dhingra and Sinclair, 1993), using selective mediums. Nutrient agar, Potato Dextrose Agar and kennight media was used for estimation of bacterial populations, fungal and actinomycetes respectively. An incubation temperature of $28^{\circ} \mathrm{C} \pm 2$ for two days and $25^{\circ} \mathrm{C}$ +2 for 3 days was adopted for fungal and bacterial populations, respectively. Populations were counted, using plate count method.

\section{Results and Discussion}

\section{Bacterial population}

From the data presented in table indicated that the bacterial population at flowering stage ranges from $37.67 \times 10^{6} \mathrm{cfu} \mathrm{g}^{-1}$ soil to $89.33 \mathrm{x}$ $10^{6} \mathrm{cfu} \mathrm{g}^{-1}$ soil (2013-14) and $43.33 \times 10^{6} \mathrm{cfu}$ $\mathrm{g}^{-1}$ soil to $100.33 \times 10^{6} \mathrm{cfu} \mathrm{g}^{-1}$ soil $(2014-15)$ and at boll bursting stage it ranged from $20 \mathrm{x}$ $10^{6} \mathrm{cfu} \mathrm{g}^{-1}$ soil to $52.67 \times 10^{6} \mathrm{cfu} \mathrm{g}^{-1}$ soil (2013-14) and $19.67 \times 10^{6} \mathrm{cfu} \mathrm{g}^{-1}$ soil to $56 \mathrm{x}$ $10^{6} \mathrm{cfu} \mathrm{g}^{-1}$ soil (2014-15).

Data revealed that, significantly highest bacterial population recorded at flowering stage as compared to boll bursting stage of cotton. However, bacterial population increased at both stages in second year as compared to first year of experimentation. 
From the data presented in table 1 indicated that among the various treatments, significantly highest bacterial population $89.33 \times 10^{6} \mathrm{cfu} \mathrm{g}^{-1}$ soil (2013-14) and $100.33 \mathrm{x}$ $10^{6} \mathrm{cfu} \mathrm{g}^{-1}$ soil (2014-15) at flowering stage was recorded in treatment $\mathrm{T}_{3}$ i.e. FYM @ $10 \mathrm{t}$ $\mathrm{ha}^{-1}$ over absolute control and all other organic treatment after first trial. However after second trial same treatment was statistically equal with the application of vermicompost @ $5 \mathrm{t} \mathrm{ha}^{-1}\left(93.00 \times 10^{6} \mathrm{cfu} \mathrm{g}^{-1}\right.$ soil). In all organic manure application treatments bacterial population was recorded lowest with the application of castor cake@ @ $500 \mathrm{~kg} \mathrm{ha}^{-1}$ at 50 per cent flowering stage. Significantly lowest bacterial population was observed at flowering stage in absolute control i. e. $37.67 \times 10^{6} \mathrm{cfu}$ $\mathrm{g}^{-1}$ soil (2013-14) and $35.33 \times 10^{6} \mathrm{cfu} \mathrm{g}^{-1}$ soil (2013-14). Amongst green manuring treatments, its combination with FYM recorded significantly higher bacterial population over green manuring alone treatment. Increased in bacterial population with the application of FYM @ $10 \mathrm{t} \mathrm{ha}^{-1}$ over absolute control treatment $\left(\mathrm{T}_{8}\right)$ was 137.13 per cent and 183.98 per cent in both the year i. e. 2013-14 and 2014-15, respectively.

From the data it was observed that significantly highest bacterial population $52.67 \times 10^{6} \mathrm{cfu} \mathrm{g}^{-1}$ soil (2013-14) and 56.00 cfu $\mathrm{g}^{-1}$ soil (2014-15) at boll bursting stage was recorded with the application of FYM @ $10 \mathrm{t} \mathrm{ha}^{-1}$ over absolute control and statistically equal with the application of VC $5 \mathrm{t} \mathrm{ha}^{-1}$ $\left(51.33 \times 10^{6} \mathrm{cfu} \mathrm{g}^{-1}\right.$ soil $)$ and sunhemp + FYM i. e. $49.00 \times 10^{6} \mathrm{cfu} \mathrm{g}^{-1}$ soil. However after second trial same treatment was found significant over all organic treatments and absolute control. In all organic manure application bacterial population was recorded lowest with the application of castor cake @ $500 \mathrm{~kg} \mathrm{ha}^{-1}$. Significantly lowest bacterial population was recorded at boll bursting stage in absolute control i. e. $20.00 \times 10^{6} \mathrm{cfu} \mathrm{g}^{-1}$ soil (2013-14) and $19.67 \times 10^{6} \mathrm{cfu} \mathrm{g}^{-1}$ soil (2014-
15). Increased in bacterial population with the application of FYM @ $10 \mathrm{t} \mathrm{ha}^{-1}$ over absolute control treatment $\left(\mathrm{T}_{8}\right)$ was 163.35 per cent and 184.69 per cent in the year of 2013-14 and 2014-15, respectively.

The increment in the bacterial population at both the critical stages of cotton under study was estimated as increased in the doses of vermicompost and FYM. Chandramohan et al., (2002) observed that the population of fungi, actinomycetes and bacteria were higher during vegetative and flowering stage as compare to harvest stage and also reported that significantly higher microbial population in sunhemp + vermicompost followed by sunhemp + poultry treatment. The lowest population was recorded in treatment receiving inorganic sources of nitrogen. The results are in line with findings reported by Ghodpage et al., (2009), (Chatto et al., 2010) and Shwetha et al., (2011).

\section{Fungal population}

The soil microfouna is the most living part of soil mainly responsible for decomposition and nutrient stabilization in soil. The results showed in Table 1. Statistical significantly influence of organic sources on fungal population presented in table 1 the result indicated that the fungal population at flowering stage ranged from $23.00 \times 10^{4} \mathrm{cfu} \mathrm{g}^{-}$ ${ }^{1}$ soil to $48.67 \times 10^{4} \mathrm{cfu} \mathrm{g}^{-1}$ soil (2013-14) and $20.00 \times 10^{4} \mathrm{cfu} \mathrm{g}^{-1}$ soil to $52.67 \times 10^{4} \mathrm{cfu} \mathrm{g}^{-1}$ soil (2014-15) and at boll bursting stage it ranged from $13.67 \times 10^{4} \mathrm{cfu} \mathrm{g}^{-1}$ soil to $31.00 \mathrm{x}$ $10^{4} \mathrm{cfu} \mathrm{g}^{-1}$ soil (2013-14) and $12.00 \times 10^{4} \mathrm{cfu}$ $\mathrm{g}^{-1}$ soil to $39.00 \times 10^{4} \mathrm{cfu} \mathrm{g}^{-1}$ soil (2014-15).

The higher fungal population was observed at flowering stage and decrease with the age of crop and lower fungal count was observed at boll bursting stage as compare to flowering stage. Similar trend was reported by Ritu Patil (1999) observed that, microbial population 
decreased markedly from grand growth stage than the harvesting stage. From the data presented in table 1 indicated that among the various treatments, significantly highest fungal population $48.67 \times 10^{4} \mathrm{cfu} \mathrm{g}^{-1}$ soil (2013-14) at flowering stage was recorded in treatment $\mathrm{T}_{3}$ i.e. FYM @ $10 \mathrm{t} \mathrm{ha}^{-1}$ over absolute control and all other organic treatment in both the year of experimentation.

Significantly lowest fungal population was recorded at flowering stage in absolute control i. e. $23.00 \times 10^{4} \mathrm{cfu} \mathrm{g}^{-1}$ soil (2013-14) and $20.00 \times 10^{4} \mathrm{cfu} \mathrm{g}^{-1}$ soil (2013-14). Increased in fungal population with the application of FYM (a) $10 \mathrm{t} \mathrm{ha}^{-1}$ over absolute control treatment $\left(\mathrm{T}_{8}\right)$ was 116.32 per cent and 225.00 per cent in the year of 2013-14 and 2014-15, respectively.

From the data it was observed that significantly highest fungal population $31.00 \mathrm{x}$ $10^{4} \mathrm{cfu} \mathrm{g}^{-1}$ soil (2013-14) and $39.00 \times 10^{4} \mathrm{cfu}$ $\mathrm{g}^{-1}$ soil (2014-15) at boll bursting stage was recorded with the application of FYM @ $10 \mathrm{t}$ $\mathrm{ha}^{-1}$ over absolute control and statistically equal with the application of sunhemp + FYM i. e. $30.67 \times 10^{4} \mathrm{cfu} \mathrm{g}^{-1}$ soil after first trial.

However after second trial same treatment was at par with sunhemp + FYM i. e. $37.00 \times 10^{4}$ $\mathrm{cfu} \mathrm{g}^{-1}$ soil and VC $5 \mathrm{t} \mathrm{ha}^{-1}\left(37.67 \times 10^{4} \mathrm{cfu} \mathrm{g}^{-1}\right.$ soil). Significantly lowest fungal population was recorded in absolute control i. e. $13.67 \mathrm{x}$ $10^{4} \mathrm{cfu} \mathrm{g}^{-1}$ soil (2013-14) and $12.00 \times 10^{4} \mathrm{cfu}$ $\mathrm{g}^{-1}$ soil (2014-15). Increased in fungal population with the application of FYM @ 10 t ha ${ }^{-1}$ over absolute control treatment $\left(\mathrm{T}_{8}\right)$ was 126.77 per cent and 225.00 per cent in the year of 2013-14 and 2014-15, respectively.

In all organic manure application fungal population was recorded lowest with the application of castor cake @ $500 \mathrm{~kg} \mathrm{ha}^{-1}$ at both the grand growth stage. Amongst green manuring treatments, its combination with FYM recorded significantly higher fungal population over green manuring alone treatment. Tripathi et al., (1980) reported that the green manuring treatments in general, increased population in total fungi and total bacteria. It might be due to addition of organic matter into the soil.

The fungi rapidly grow and are almost double in their population as compared to control while at boll bursting their population decline to some extent. Similar results were also reported by Badole and More (2001) who reported that organic treatment recorded higher microbial population than inorganic treatments or absolute control. The results are in line with findings reported by Ghodpage et al., (2009), (Chatto et al., 2010) and Shwetha et al., (2011).

\section{Actinomycetes population}

Role of organic sources in altering the microbial population dynamics in soil is further evidenced by spectacular effect of organic sources and biofertilizer. Use of organic manures and biofertilizer resulted in triggering the actinomycetes population.

The results indicated in general the highest actinomycetes colonies was recorded during flowering stage and decline at boll bursting stage as shown in Table 1. Chandramohan (2002) observed that, the population of fungi, actinomycetes and bacteria were higher during vegetative and flowering stage as compare to harvest stage.

The data presented in table 1 indicate that the actinomycetes population at flowering stage ranged from $34.00 \times 10^{4} \mathrm{cfu} \mathrm{g}^{-1}$ soil to $110 \mathrm{x}$ $10^{4} \mathrm{cfu} \mathrm{g}^{-1}$ soil (2013-14) and $33.67 \times 10^{4} \mathrm{cfu}$ $\mathrm{g}^{-1}$ soil to $114.67 \times 10^{4} \mathrm{cfu} \mathrm{g}^{-1}$ soil $(2014-15)$ and at boll bursting stage it ranged from 21.33 x $10^{4} \mathrm{cfu} \mathrm{g}^{-1}$ soil to $67.00 \times 10^{4} \mathrm{cfu} \mathrm{g}^{-1}$ soil (2013-14) and $18.00 \times 10^{4} \mathrm{cfu} \mathrm{g}^{-1}$ soil to 72.65 x $10^{4} \mathrm{cfu} \mathrm{g}^{-1}$ soil (2014-15). 
Table.1 Effect of organic sources on microbial population in Vertisols at grand growth stages under cotton

\begin{tabular}{|c|c|c|c|c|c|c|c|c|c|c|c|c|}
\hline \multirow{4}{*}{$\begin{array}{l}\text { Treatment } \\
\text { Detail }\end{array}$} & \multicolumn{4}{|c|}{ Bacterial population } & \multicolumn{4}{|c|}{ Fungal population } & \multicolumn{4}{|c|}{ Actinomycetes population } \\
\hline & $\begin{array}{c}2013- \\
14\end{array}$ & $\begin{array}{c}2014- \\
15\end{array}$ & $\begin{array}{c}2013- \\
14\end{array}$ & $\begin{array}{c}2014- \\
15\end{array}$ & $2013-$ & $\begin{array}{c}2014- \\
15\end{array}$ & $2013-$ & $\begin{array}{c}2014- \\
15\end{array}$ & $2013-$ & $\begin{array}{c}2014- \\
15\end{array}$ & $2013-$ & $\begin{array}{c}2014- \\
15\end{array}$ \\
\hline & \multicolumn{2}{|c|}{$\begin{array}{l}\text { At } 50 \% \\
\text { flowering }\end{array}$} & \multicolumn{2}{|c|}{ At $50 \%$ BB } & \multicolumn{2}{|c|}{$\begin{array}{l}\text { At } 50 \% \\
\text { flowering }\end{array}$} & \multicolumn{2}{|c|}{ At $50 \%$ BB } & \multicolumn{2}{|c|}{$\begin{array}{l}\text { At } 50 \% \\
\text { flowering }\end{array}$} & \multicolumn{2}{|c|}{ At $50 \%$ BB } \\
\hline & \multicolumn{4}{|c|}{ (cfu $10^{6} \mathrm{~g}^{-1}$ soil) } & \multicolumn{4}{|c|}{ (cfu $10^{4} \mathrm{~g}^{-1}$ soil) } & \multicolumn{4}{|c|}{$\left(\right.$ cfu $10^{4} \mathrm{~g}^{-1}$ soil $)$} \\
\hline $\begin{array}{l}\text { T1 - FYM } 5 \text { t } \\
\text { ha }^{-1}\end{array}$ & 67.33 & 89.56 & 33.33 & 49.33 & 43.67 & 43.67 & 25.33 & 32.00 & 91.00 & 107.67 & 56.33 & 62.67 \\
\hline $\begin{array}{l}\text { T2 - VC } 2.5 \mathrm{t} \\
\mathrm{ha}^{-1}\end{array}$ & 61.33 & 82.56 & 34.67 & 50.67 & 37.33 & 41.33 & 22.67 & 31.33 & 94.00 & 103.33 & 58.65 & 61.61 \\
\hline $\begin{array}{l}\text { T3 - FYM } 10 \\
\text { t ha }\end{array}$ & 89.33 & 100.33 & 52.67 & 56.00 & 48.67 & 52.67 & 31.00 & 39.00 & 110.00 & 114.67 & 67.00 & 72.65 \\
\hline $\begin{array}{l}\text { T4 - VC } 5 \text { t } \\
\text { ha }^{-1}\end{array}$ & 73.00 & 93.00 & 49.00 & 51.33 & 42.00 & 39.00 & 28.00 & 37.67 & 103.67 & 112.33 & 64.33 & 68.33 \\
\hline $\begin{array}{l}\text { T5 - In situ } \\
\text { green } \\
\text { manuring } \\
\text { with } \\
\text { Sunhemp }\end{array}$ & 73.33 & 82.56 & 34.00 & 50.00 & 37.00 & 38.33 & 23.00 & 33.33 & 91.00 & 95.33 & 56.33 & 61.68 \\
\hline $\begin{array}{l}\text { T6 - Castor } \\
\text { cake @500 kg } \\
\text { ha }^{-1}\end{array}$ & 58.00 & 70.67 & 36.00 & 50.67 & 31.00 & 37.67 & 28.33 & 30.00 & 85.00 & 89.62 & 51.62 & 56.61 \\
\hline $\begin{array}{l}\text { T7 - } \\
\text { Sunhemp + } \\
\text { FYM (source } \\
\text { of } 15 \mathrm{~kg} \\
\left.\mathbf{P}_{2} \mathrm{O}_{5}\right)\end{array}$ & 81.67 & 90.00 & 51.33 & 52.67 & 38.67 & 42.33 & 30.67 & 37.00 & 92.31 & 96.33 & 61.33 & 66.33 \\
\hline T8-Control & 37.67 & 35.33 & 20.00 & 19.67 & 23.00 & 20.00 & 13.67 & 12.00 & 34.00 & 33.66 & 21.33 & 18.00 \\
\hline $\mathrm{SE}(\mathrm{m}) \pm$ & 1.84 & 2.58 & $21^{\prime}$ & 3.07 & 1.42 & 1.62 & 0.85 & 1.57 & 1.20 & 1.91 & 1.21 & 1.11 \\
\hline CD at $5 \%$ & 5.47 & 7.66 & 4.06 & 9.13 & 4.23 & 4.81 & 2.52 & 4.66 & 3.56 & 5.66 & 3.61 & 3.29 \\
\hline
\end{tabular}

From the data it was observed that at flowering stage significantly highest actinomycets population $110.00 \times 10^{4} \mathrm{cfu} \mathrm{g}^{-1}$ soil (2013-14) and $114.67 \times 10^{4} \mathrm{cfu} \mathrm{g}^{-1}$ soil (2014-15) was recorded with the application of FYM @ $10 \mathrm{t} \mathrm{ha}^{-1}$ over absolute control and all other organic treatments after first trial (2013-14). However after second trial same treatment was at par with VC $5 \mathrm{t} \mathrm{ha}^{-1}(112.33 \mathrm{x}$ $10^{4}$ cfu $\mathrm{g}^{-1}$ soil). Significantly lowest actinomycetes population was recorded in absolute control i. e. $34 \times 10^{4} \mathrm{cfu} \mathrm{g}^{-1}$ soil (2013-14) and $33.66 \times 10^{4} \mathrm{cfu} \mathrm{g}^{-1}$ soil (201314). Increased in actinomycets population with the application of FYM @ $10 \mathrm{t} \mathrm{ha}^{-1}$ over absolute control treatment $\left(\mathrm{T}_{8}\right)$ was 223.52 per cent and 240.67 per cent in the year of 201314 and 2014-15, respectively.

From the data it was observed that at boll bursting stage significantly highest actinomycets population $67.00 \times 10^{4} \mathrm{cfu} \mathrm{g}^{-1}$ 
soil (2013-14) and $72.65 \times 10^{4} \mathrm{cfu}^{-1}$ soil (2014-15) was recorded with the application of FYM @ $10 \mathrm{t} \mathrm{ha}^{-1}$ over absolute control and statistically equal with the application VC $5 \mathrm{t}$ $\mathrm{ha}^{-1}$ i. e. $64.33 \times 10^{4} \mathrm{cfu} \mathrm{g}^{-1}$ soil after first trial. Significantly lowest actinomycets population was recorded in absolute control i. e. $21.33 \mathrm{x}$ $10^{4} \mathrm{cfu} \mathrm{g}^{-1}$ soil (2013-14) and $18.00 \times 10^{4} \mathrm{cfu}$ $\mathrm{g}^{-1}$ soil (2014-15). Increased in actinomycets population with the application of FYM @ 10 t ha ${ }^{-1}$ over absolute control treatment $\left(\mathrm{T}_{8}\right)$ was 214.11 per cent and 303.61 per cent in the year of 2013-14 and 2014-15, respectively.

In all organic manure application actinomycets population was recorded lowest with the application of castor cake @ $500 \mathrm{~kg}$ $\mathrm{ha}^{-1}$ at both the grand growth stage. Amongst green manuring treatments, its combination with FYM recorded significantly higher actinomycets population over green manuring alone treatment. These results were in agreement with the finding of Naidu et al., (1999) and Singh et al., (2007) who reported that soil microbial population enhanced due to application of organic amendments in comparison to absolute control.

The lowest actinomycetes population recorded in treatment Sunhemp in situ $\left(87.33 \times 10^{4} \mathrm{cfu}\right.$ $\mathrm{g}^{-1}$ at flowering stage and $54.17 \times 10^{4} \mathrm{cfu} \mathrm{g}^{-1}$ at boll bursting stage) among all the organic treatments.

The results indicated in general the highest microbial colonies were recorded during flowering stage and decline at boll bursting stage. The study revealed that significantly highest microbial population in the rhizosphere of cotton during 50\% flowering as well as $50 \%$ boll bursting stage was recorded with treatment $\mathrm{T}_{3}$ (FYM $10 \mathrm{t} \mathrm{ha}^{-1}$ ). Results of significant improvement in the microbial population in rhizosphere of cotton at flowering and boll bursting stage due to use of organic nutrients viz., vermicompost, FYM, castor cake and in situ green manuring. Due to the fact that, it serve as food and energy for bacteria, fungi and actinomycetes was higher than later boll bursting stage might be due to microbes attack the food material and increase their colonies and which was decreased as reduction in the quantity of food material.

\section{References}

Azam, M. and R.D. Banerjee, 1989. Population dynamics of rhizosphere micro flora of chilli plants as influenced by the application of fertilizers. Environment and Ecology, 7: 813-820.

Badole, S. B. and S. D. More, 2001. Effect of Integrated Nutrient Management system on the changes in soil microbial population under cotton-groundnut cropping system. Indian Soc. Cotton improve August 83-87.

Chandramohan, S. 2002. Studies on organic farming in cotton plus black gram intercropping. M.Sc. (Agri.) Thesis (unpub.) TNAT, Coimbatore pp: 5597.

Chattoo, M.A., N. Ahmed, M.V. Zargar, S. Narayan and S.N. Parry, 2010. Effect of organic manures and inorganic fertilizers on rhizosphere fungal and bacterial population. Prog. Agric., 10 (Special Issue): 67-70.

Dingra, O. D. and J. B. Sinclair, 1993. Basic plant pathology method, CBS pub. Delhi, pp.174-180.

Ganeshe, R.K., Pandey, R.P and Rawat, A.K. 1998. Comparative performance of biofertilizers and chemical nitrogen on yield of okra. Horticultural Journal, 11:53

Ghodpage, R. M., S. S. Balpande, M. A. Harale and Madhumita G. Mandle, 2009. Effect of amrutpani and biofertilizer with fertilizer and vermicompost on soil micro biota and 
yield of rainfed cotton. J. Soils and Crops, 19 (2): 343-346.

Halemani, H. L., S. S. Hallikeri; S. S. Nooli, R. A. Nandagavi and H. S. Harish Kumar, (2004). 1. Effect of organics on cotton productivity and physicochemical properties of soil. In: International symposium on "Strategies for sustainable cotton production-A global vision". 2. Crop production, 23-25, Nov. 2004, VAS, Darwad: pp. 174-180.

Maheswarappa, H. P., H. V. Nanjappa and M. R. Hegde, 1999. Influence of organic manures on yield of arrowroot soil physic-chemical and biological properties when grown as intercrop in coconut garden. Ann. Agric. Res. 20(3): 318-323.

Naidu, A. K., S. S. Kushwan and V. C. Dwivedi, 1999. Performance of organic manure, bio and chemical fertilizers and their combinations on microbial population of soil and growth yield of okra. JNKVV Res. J., 33 (1-2): 34-38.

Ritu Patil, 1999. Dynamics of soil nitrogen as influenced by cropping system and nitrogen management Ph.D. (agri.) Thesis (unpub.), Dr. P.D.K.V. Akola.

Sharma, M. P., S. V. Bali and D. K. Gupta, 2000. Crop yield and properties of inceptisol as influenced by residual management under rice-wheat cropping sequence. J. Indian Soc. Sci. 48(3): 506-509.

Shwetha, S., J. Narayana, B. V. shwetha and R. Girish, 2011. Effect of vermicompost on soil bacterial and fungal populations in rice crop (Oryza sativa L.). Mysore J.agric. sci., 45(1): 7-10.

Singh, Y. V., B. V. Singh, S. Pabbi and P. K. Singh, 2007. Impact of organic farming on yield and quality of Basmati rice and soil properties. http://orgprints.org/view/projects/wise enschaftagung, 2007.html.

Tripathi, K. S. and J. C. Edward, 1980. Green manuring in relation to vertical distribution of microorganisms in soil. J. Indian Soc. Soil Sci. 28 (1): 134135.

\section{How to cite this article:}

Jayshree A. Khuspure, S. M. Bhoyar, P. W. Deshmukh, A. N. Paslawar and Gabhane, V. V. 2019. Organic Manures: A Way to Improve Rhizospheral Microbial Population under Organic Cotton in Vertisols. Int.J.Curr.Microbiol.App.Sci. 8(10): 82-88. doi: https://doi.org/10.20546/ijcmas.2019.810.009 